$$
\begin{aligned}
& \text { SF } 240 \\
& .86
\end{aligned}
$$





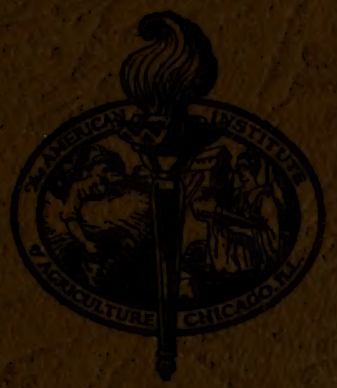

\section{MARKETING DAIRY PRODUCTS} LESSON 2

$$
\therefore \because
$$

Confidential Edition Issued for Members 
$\because \vdots$

(C) 01.6 .62120

$$
\text { JAN }-223
$$

ans 


\section{$S F_{240}$
.96}

THE MAN WHO CONDUCTS THIS LESSON

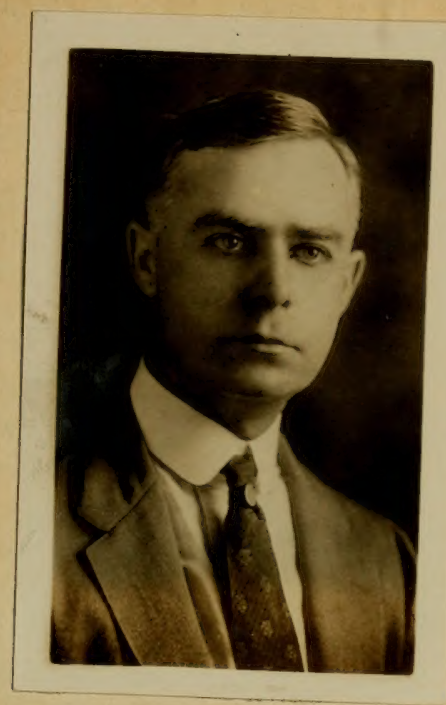

ROY C. POTTS

Having grown up with the development of the dairy manufacturing industry, and having been in intimate contact with it because of his official position in the Department of Agriculture, it is fortunate that Prof. Potts was secured to prepare these lessons.

Since 1915, he has been in charge of the dairy and poultry marketing work in the Department, and has not only watched the development of dairy manufacturing, but has had a great deal to do with encouraging and directing its development. During the time Prof. Potts has been engaged in this work, the manufacturing industry has gone through an important evolution, and Prof. Potts understands not only the details of the development, but the reasons for the development.

Before coming to the Department of Agriculture in 1915, Prof. Potts was in charge of dairying at the Oklahoma Agricultural and Mechanical College at Stillwater, Okla. He was in that position for 10 years. 
Between 1913 and 1915, he was the dairy editor of the "Oklahoma Farmer Stockman, "and as such he traveled a great deal among the dairies of 0klahoma and the adjoining states.

Prof. Potts has an enviable standing among both the dairymen of the country, the manufacturing interests, and dairy scientists. He is a member of the American Dairy Science Association, the American Farm Economics Association, and the National Association of State Marketing Officials. So you see, he has had a great deal to do with the advance of dairy production and marketing methods.

While he has been the autfior of many government bulletins on marketing, the book for which he is best known is "Dairy Laboratory Outlines," which was published in 1912 .

You will enjoy studying Prof. Potts' lessons, both because of his simple and straightforward method of expression, and because of the authority with which he speaks.

SUMMARY OF PROPESSOR ROY C. POTTS' TRAINING AND EXPERIENGE

EXPERIENCE: Specialist, in charge Dairy and Poultry Marketing, Bureau of Agricultural Economics, U. S. Department of Agriculture, since Pebruary, 1915

Professor, in charge Dairying, Oklahoma Agricultural and Mechanical College, Stillwater, Okla, 1905-15

Taught rural graded school, 1903-06

Dairy Editor, 'Oklahoma Farmer Stockman,"' 1913-15

MEMBER: American Dairy Science Association, American Farm Bconomics Association, National Association. State Marketing Officials

AUTHOR: “Dairy Laboratory Outlines,'" 1912; various government bulletins on marketing and dairy products

EDUCATIOH: B. S. Michigan Agricultural College, 1906

HOW TO STUDY THIS IESSON

Before you have gone far in this course, you will begin to realize that the manufacture of dairy products is unusually important, due to the fact that such a large part of milk and cream is manufactured into other products before it is sold to the final consumer. It is important, therefore, that you thoroughly familiarize yourself with the manufacturing situation. 


\section{First, Learn Which States Are Most Important}

To master Part $I$, you will probably find it necessary to spend two, or possibly three study periods. That section of Part I that will probably be most difficult to master is the one entitled "Important Dairy Manufacturing States."

You may think at first that you will have little need for such information as this in everyday work, but no one can really become successful in any part of the marketing of dairy products unless he is thoroughly familiar with the source of production.

IMPORTANT DAIRY MANUFACTURING STATES

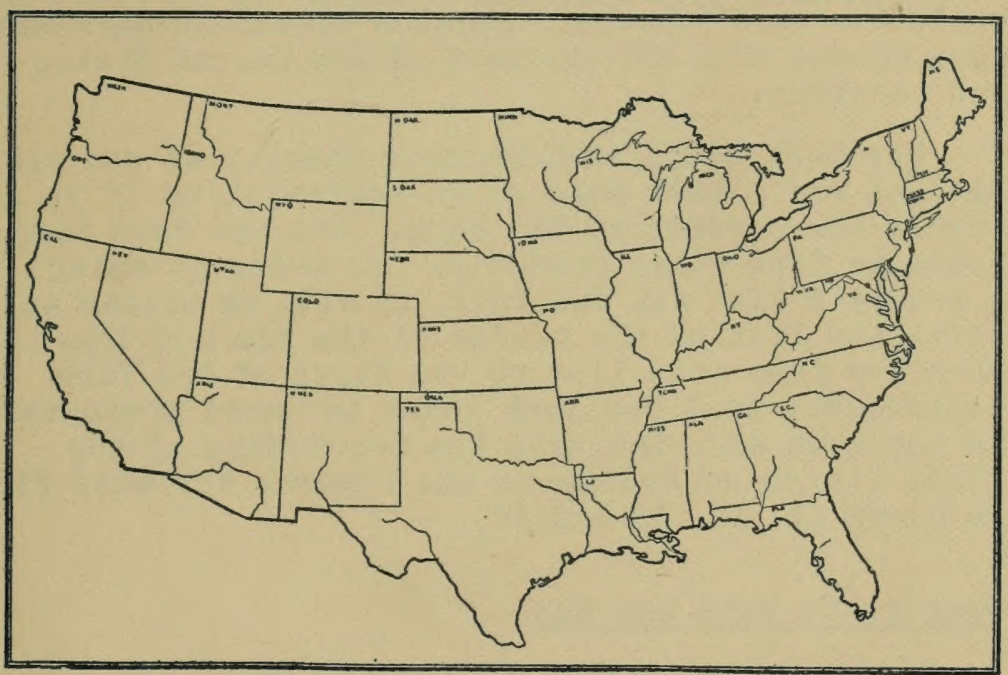

Numbers indicate the rank of states in the manufacture of all dairy products. Names of products indicate that the state in which the name is written leads all others in the manufacture of that product

How To Use The Map

An outline map of the United States is provided with these study suggestions, in order to help you learn the importance of the various states in the manufacture of dairy products.

The way to use this map is to write rirst the number that represents the rank of each state, placing the number within the borders of the state on the map. This will help wonderfully in fixing the order of rank of the various states in your mind. 
After you have this done, study the map carefully and recite to yourself all that you remember of the reasons why the various states excel in the products which they manufacture in important quant1ties.

Now, print the name of the product within the borders of the state in which that state leads all others. For example: you will write "creamery butter" within the borders of the state of Minnesota; you will write "dairy butter" in Texas.

When you come to Wisconsin, you will find that you have three names to write, but they are all varieties of cheese, so it will be just as well to write the word "cheese," because Wisconsin does make more cheese than all the rest of the United States put together.

New York leads in Limburger cheese, so you will need to write that name or an abbreviation of it within the borders of New York. But New York also leads in five other products. In order to enter a complete list for New York, it will be better to write the list on the border of the map and draw an arrow from this list to the state of New York to indicate that New York leads in those products. In the same way, indicate the leadership of the other states according to the figures you will find on pages $11,12,13$ and 14 .

\section{What to Do With the Map}

After you have the map made in this way, study it carefuliy. It might be a good idea to carry it in your pocket and look at it as you have occasion during the day.

There is some exceedingly important information under the heading "How Dairy Manufacturing Plants Stabilize the Industry."

Use the map you have made, in connection with your study of Part II. As you are studying about the six classes of butter, refresh your memory as to which states produce the most butter, remembering that one class of butter is produced in largest quantity in Minnesota, whereas other classes are produced in larger quantity in Texas. 
Use the Map in Your Study of Cheese

In the same way, use the map as you are studying about the manufacture of cheese.

You should spend at least one study period, or perhaps two, in the study of the second part of the lesson.

Discuss Dairy Manufacture With Others

It will greatly help if you will discuss what you have learned with someone else. Pick out the points in the lesson that you think are not known by some of your friends and talk with them about those points. 


\section{STUDY OUTLINE}

Part 1. The Importance of the Industry 7

The Producers' Interest in Dairy Manufacturing 8 The Manufacturers' Interest in the Producer.. 9

Scope of the Dairy Manufacturing Industry 10

Important Dairy Manufacturing States $\quad 11$

Why New York Is the First State.......... II

How Wisconsin Excels..................... 11

Pennsylvania Holds Third Place........... 12

Minnesota Is Fourth................... 12

Michigan Is Fifth................... 12

Ohio Comes Sixth..................... 13

California Is Seventh................. 13

Dairy Butter Production................ 13

Oregon An Important Dairy Manufacturing State. 13

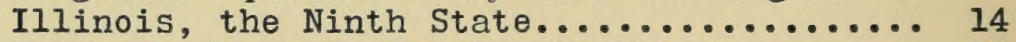

Nebraska Leads in Buttermilk Powder........ 14

How Dairy Manufacturing Plants Stabilize the

Industry 14

Market Milk Prices Stabilized by Manufacturing 15

Classes of Dairy Products 16

Milk Composition and Value............ 16

Cream, Its Composition and Value......... 18

Part II. Classes of Dairy Manufacturing Plants 19

Processing Plants Defined............... 19

Manufacturing Plants Defined............. 20

Butter and Its Six Classes................ 21

The Manufacture of Cheese $\quad 27$

Varieties of Cheese.................. 28

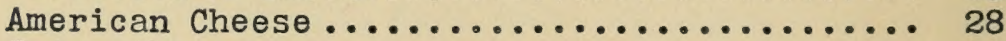

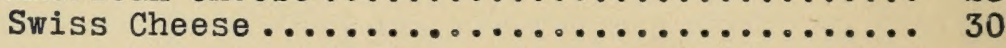

Condensed and Evaporated Milk 31

Milk Powder 33

Uses of Milk Powder.................. 33

Buttermilk Powder................... 34 


\title{
ORGANIZATION FOR THE MANUFACTURE OF DAIRY PRODUCTS
}

\author{
BY ROY C. POTTS
}

A student of dairy marketing should know not only how dairy products are marketed in the various trade channels, but he should also know how each branch of the industry is organized; how it functions, and how it renders an economic service in relation to other branches. This knowledge should give the student a broader view of the problems of marketing and prepare him to solve them.

It is this broader view that is most needed, for, too frequently, producers, manufacturers, distributors, and market men see only the product and the dollars they desire to get out of it. They know very little about the problems of marketing except that part with which they are directly and intimately concerned. Consequently, they can be of but little real assistance to any other group.

This has resulted in a lack of sympathy and cooperation between producers, manufacturers, distributors, and consumers-a condition which hinders rather than helps the advance of the dairy industry.

It is essential, therefore, that students of dairy marketing obtain a knowledge not only of distribution, but also of production and manufacture. With this knowledge, any one is better prepared for formulating constructive plans for better marketing.-Editor's Note.

\section{PART I}

THE IMPORTANCE AND SCOPE OF THE DAIRY MANUFACTURING INDUSTRY

It is true that producers, manufacturers, and distributors are all in business because they each expect to receive a profit from their efforts, but each also renders a service to the other which should be recognized. Neither would be able to 
succeed without the services of the others.

While the consumer makes the demand which develops the market, it requires the services of the manufacturer and the distributor to get the products from the producer to the consumer. And other direct and contributing services are often required, such as were mentioned in Lesson $B$ in which you learned about the operation of the marketing machinery.

Need For Dairy Manufacturing Obvious

The essential need for dairy manufacturing is readily obvious. Milk and cream are quickly perishable food products under ordinary conditions. Areas remote from large cities or fluid milk markets would be practically devoid of a satisfactory market were it not for the dairy manufacturing industry which converts the quickly perishable milk and cream into less perishable products such as butter, cheese, milk powder, condensed milk, etc.

Manufacturing Promotes Dairy Development

In fact, it has often been the establishment of a dairy manufacturing plant in a community that has given the community a satisfactory market for its dairy products and thus made possible thousands of rather extensively developed dairy sections.

It should not be inferred that dairy factories precede extensive dairy production, for such is not necessarily true. A certain amount of production is required for the successful operation of a dairy manufacturing plant, but with such a plant able to furnish a profitable market for a larger production it is but logical for larger production to result, provided dairy production is as profitable in the community as other branches of farming.

The Producers Interest in Dairy Manufacturing

Producers, dependent upon dairy manufacturing concerns for a market, have a deep and vital interest in the business policy, methods, and ef- 
ficiency of the concern they patronize. Their returns will be affected by the quality of product manufactured, the market obtained for it, and the cost of manufacture and marketing.

The fact remains that producers, except where they own and operate their own manufacturing plants, are dependent upon the services of others. Unless this service is efficiently and equitably rendered, the producers may be the losers from inefficient and uneconomical manufacturing methods. When such uneconomical methods exist, organized rather than Individual efforts of the producers may be most effective in bringing about the needed improvement. Sometimes the best thing to do is to secure a more satisfactory outlet through other manufacturing concerns or by organizing a cooperative manufacturing organization.

\section{The Manufacturer's Interest in the Producer}

The manufacturer cannot select a location for a dairy plant at random. His chances for success would be small. He must be assured that the necessary volume of raw material (milk or cream) is available in the community or territory tributary to his proposed factory. If the available supply of raw material is large and the price received by producers is relatively low, or the tendency of producers is toward larger production, possibilities of success are far greater than where opposite conditions exist.

The manufacturer who has his own and the producers interest at heart, will endeavor to maintain or even increase production. His overhead operating costs per unit of product manufactured will be decreased as his volume of output increases, hence increased production should benefit both the producer and manufacturer.

He will study the producer's problem of production to the end that he may give assistance in lowering production costs and improving the quality 
of product, thus increasing the producer's profits and encouraging both a continued and increased production.

Many progressive manufacturers take a broad view of the producer's production and marketing problem, for they realize their interests and the producers' are closely related, and their success is to a large degree dependent upon the success of the producer.

\section{SCOPE OF THE DAIRY MANUFACTURING INDUSTRY}

The development of the dairy manufacturing industry has followed closely the development of dairy production. And production has grown with increased manufacturing facilities. In many communities, the small local creamery or cheese factory has pioneered the development of dairying by making a market for the milk or cream produced.

In recent years, with the building of good roads, use of motor transportation, and an improvement in transportation facilities generally, there has been a marked tendency toward fewer and larger manufacturing plants, especially in the creamery, market milk, and ice cream industries.

\section{Extent of Dairy Manufacturing}

A view of the importance and the extent of dairy manufacturing may be obtained from the fact that the number of commercial dairy manufacturing plants in the United States approximates or exceeds 10,000 and that in these plants somewhat more than $45 \%$ of all the milk and cream produced is converted into the various kinds of manufactured and processed dairy products, which have a value closely approximating one billion dollars annually.

It is obvious that to finance, maintain, and operate these plants, an enormous capital investment is required. Thousands of people must be employed and the interest on the capital investment, and the 
wages of these laborers, and the cost of the necessary supplies for manufacturing-all are very necessary parts of the cost added between the producer and the consumer. This manufacturing service must be maintained and paid for.

\section{IMPORTANT DAIRY MANUFACTURING STATES}

There are 26 states that hold an important place in the manufacture of dairy products. The rank of these states in the manufacture of the 13 most important dairy products is important for you to know.

Six states stand out as leaders, their rank being as follows:

$\begin{array}{ll}\text { 1. New York } & \text { 4. Minnesota } \\ \text { 2. Wisconsin } & \text { 5. Michigan } \\ \text { 3. Pennsylvania } & \text { 6. Ohio }\end{array}$

These states hold their respective places for the following reasons.

Why New York Is the First State

New York is first in total production in Limburger cheese, cottage, pot, and bakers' cheese, condensed milk, evaporated milk, whole milk powder, skim milk powder. She produces the second largest amount of American cheese, brick, and Munster cheese, and cream powder; she produces the third largest amount of Swiss cheese, and she stands sixth in the production of buttermilk powder.

Thus, New York holds an important place in the manufacture of 11 of the 13 important dairy products.

\section{How Wisconsin Excels}

Wisconsin produces more cheese than any other state in the Union. In fact, she produces more cheese than all of the rest of the states put together. She produces the largest amount of American cheese, Swiss cheese, and brick and Munster cheese. Sho produces the second largest amount of Limburger cheese and of creamery butter. 
She stands third in the production of $\operatorname{cottag\theta }$, pot, and bakers' cheese, condensed milk, whole milk powder, and skim milk.

She stands fourth in the production of buttermilk powder.

Thus, you see Wisconsin holds an important place in the production of 10 of the 13 important dairy products.

\section{Pennsylvania Holds Third Place}

Pennsylvania wins third place by being the leader in the production of cream powder; by holding second place in the production of dairy butter, cottage, pot, and bakers' cheese, evaporated milk, and whole milk powder. She is fourth in production of Swiss cheese and skim milk powder. She holds seventh place in the production of American cheese, brick, and Munster cheese, and condensed milk.

Thus, she holds an important rank in the production of 10 of the 13 manufactured dairy products.

\section{Minnesota Is Fourth}

Minnesota holds fourth place because she leads all of the states in the production of creamery butter. She is second in the production of buttermilk powder; third in the production of brick and Munster cheese; fifth in the production of American cheese; sixth in the production of cottage, pot, and bakers' cheese; and eighth in the production of skim milk powder.

She produces an important amount of six of the 13 manufactured dairy products.

\section{Michigan Is Fifth}

Michigan, the fifth dairy state from the standpoint of manufactured products, is second in the total production of condensed milk; third in Iimburger cheese, fourth in evaporated milk; fifth 
in skim milk powder, cottage, pot, and bakers' cheese, and Munster cheese; sixth in American cheese; seventh in buttermilk powder and creamery butter.

Thus, she produces an important amount of nine of the 13 important dairy products.

\section{Ohio Comes Sixth}

Ohio is second in the production of Swiss cheese, fourth in the production of creamery butter, brick, and Munster cheese, and cottage, pot, and bakers' cheese; fifth in dairy butter, and fifth in Limburger cheese; sixth in condensed milk; seventh in evaporated milk.

She produces important amounts of eight of the 13 important manufactured dairy products.

California Is Seventh

You should also note that California is important in the manufacture of dairy products. She makes important amounts of eight of the 13 products. She stands second in skim milk powder; fourth in American cheese; fifth in Swiss cheese, evaporated milk, whole milk powder, and creamery butter; seventh in cottage, pot, and bakers' cheese; ninth in condensed milk.

\section{Dairy Butter Production}

It is an interesting fact that only one of the 10 states producing the most creamery butter produces an important amount of dairy butter. That state is Ohio, which stands fourth in the production of creamery butter and fifth in the production of dairy butter.

Texas leads in the production of dairy butter, but does not hold an important place in any other product.

\section{Oregon an Important Dairy Manufacturing State}

You should note the important position held by Oregon. Oregon produces seven of the 13 important manufactured dairy products. 
She holds third place in the production of American cheese; fourth place in the production of limburger cheese; sixth place in the production of Swiss cheese, and brick, and Munster cheese; eighth place in the production of condensed milk; and tenth place in the production of evaporated milk, cottage, pot, and bakers' cheese.

\section{Illinois the Ninth State}

Illinois produces five of the important dairy products, standing fourth in the production of condensed milk; fifth in buttermilk powder; sixth in evaporated milk; seventh in the production of skim milk powder; and eighth in creamery butter.

\section{Nebraska Leads in Buttermilk Powder}

You should note that Nebraska leads in the production of buttermilk powder, although she is sixth in the production of creamery butter.

This will show you that, although a few years ago dairying was largely centered in eastern states, it is now centered in the Middle West.

\section{HOW DAIRY MANUFACTURING PLANTS STABILIZE}

\section{THE INDUSTRY}

Dairy manufacturing plants, as has been pointed out, have made possible the extensive commercial development of the dairy industry. They have done even more-they have given stability to the industry.

No matter how variable may be the supply of milk or cream from day to day, month to month, or season to season, the surplus produced may be converted into manufactured products.

The manufacturing industry, supplemented by the storage industry, stabilizes supply and demand, and thus gives stability to the price of dairy products. 
Manufacturing Stabilizes Prices

In the absence of stability in supply and demand, there is a constant fluctuation in prices, which increases the risks and possibilities of loss to producers, manufacturers, and distributors, and causes more or less uncertainty in the minds of consumers.

These conditions neither encourage production nor consumption and therefore are not desired. $\mathrm{Be}-$ cause of the fact that the value of milk and cream for manufacturing is reflected directly from the market value of the manufactured products, the price of milk and cream becomes stabilized when the price of manufactured products is stable.

\section{Market Milk Prices Stabilized by Manufacturing}

In most regions supplying fluid milk and cream to cities, the supply is quite generally in excess of the needs, and the surplus must be converted into manufactured products.

The manufacturing plants, act, so-to-speak, like safety valves on production and relieve the market of a glutted supply. They also tend to establish a minimum price for market milk, which is the manufacturing value of the surplus produced.

This manufacturing value also tends to operate as a "governor" on the price of fluid milk and cream sold to city milk distributors, for if the city price rises to a figure greatly higher than the manufacturing value, and the country sources of supply are uncontrolled, there is a tendency for owners of the uncontrolled supply to attempt to find a market among the city milk dealers, even at a lower price than the prevailing fluid milk price, but still above the manufacturing value of the milk.

This possible offering of milk, regularly used for manufacturing, at prices slightly higher than its manufacturing value is a competitive factor which rather tends to stabilize fluid milk and cream 
prices at figures near the manufacturing value.

Thus the manufacturing industry is both a safety valve on production and a regulator or stabilizer of prices.

\section{CLASSES OF DAIRY PRODUCTS}

Milk Composition and Value

Milk has been defined in broad terms as "the normal secretion of the mammary glands of animals which suckle their young." In some foreign countries, the milk of sheep and goats is used, but in the United States, the milk of cows is almost exclusively used in commercial trade channels.

A number of large herds of milch goats are kept in California, and some smaller herds and individual milch goats are scattered throughout the country. The milk of the goat contains a very high percentage of butter fat and total solids and is recognized as specially adapted for use in making cheese, especially in foreign countries where the "Roquefort" is chiefly made from goats' milk.

Composition of Cow's Milk - The normal composition of cow's milk in its whole and unadulturated form is given by Michels as follows:

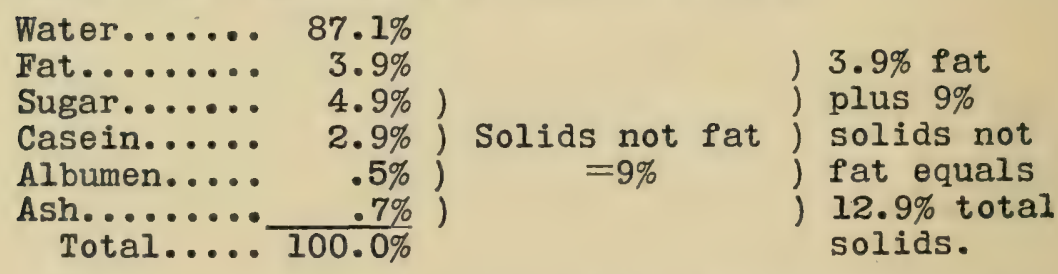

Food Value of Milk-It will be noted that in 100 pounds of milk there are nearly 13 pounds of edible and digestible solids, of which approximately $30 \%$ is fat, nearly $40 \%$ is sugar, and nearly $30 \%$ is casein and albumen. (See also Figure 1.)

That milk is a complete food is evidenced by the fact that infants live for a period and thrive and grow fat on it alone. It is highly digestible and 
nutritious and contains the elements of vitamines so important in stimulating growth and maintaining normal body functions and good health conditions.

In fact, the food products made from milk and cream possess these vitamine qualities and also rank high in food value. For these reasons, the

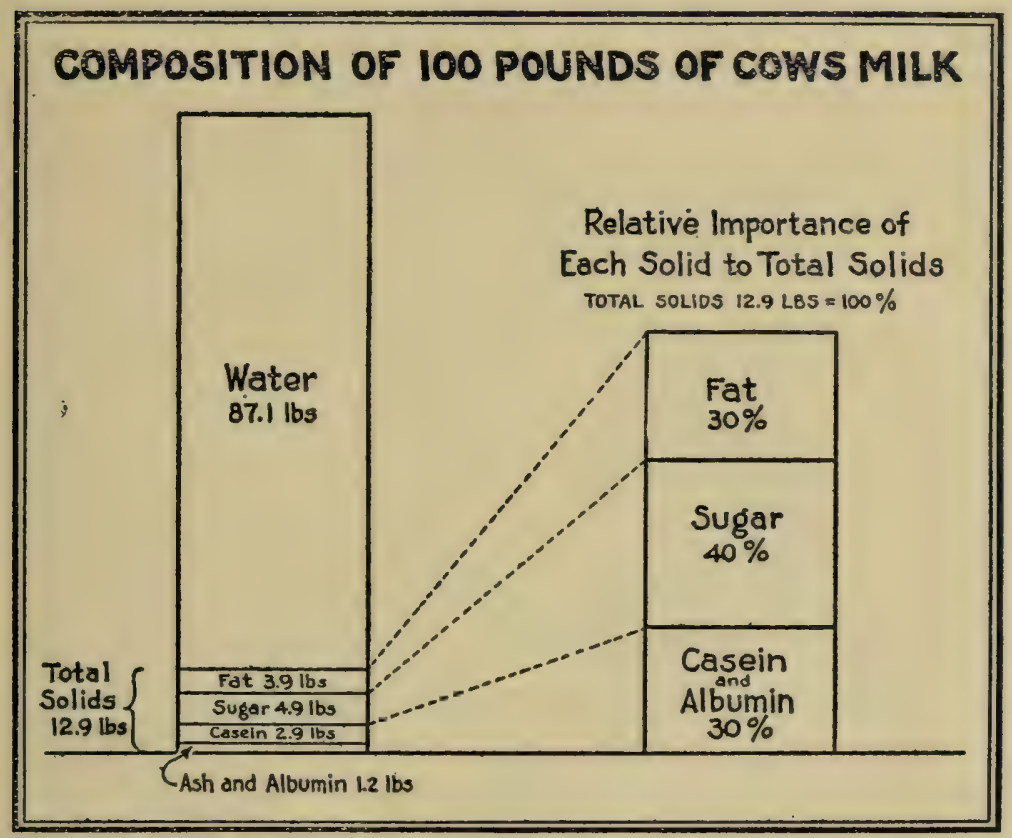

FIGURE 1. WHY COW'S MILK IS SUCH A VALUABLE FOOD This chart illustrates the content of cow's milk. You will see that all of the total solids are unusually valuable nutritious elements

consumption of dairy products in larger quantities is recommended and is being urged by health authorities and by organizations and agencies interested in public health work and in the future development of the dairy industry.

Such work is being supported by producers, manufacturers, and distributors of dairy products, for in it they see possibilities for increasing the demand and use of dairy products and thereby the further development of their own business. 


\section{Cream, Its Composition and Value}

Cream is the product obtained by skimming or removing from milk, the fat content together with a part of the non-fat content. Cream was previously skimmed from the surface of milk by hand with a ladle, after it had risen to the surface. Now cream usually is separated by means of centrifugal separators.

The advantages of the centrifugal process of separating the cream are that less fat is left in the skimmed milk and a higher quality of cream may generally be obtained.

Under the hand process of skimming it was not uncommon to delay the skimming until the milk had soured or clabbered. While in the centrifugal process, the cream is skimmed from the fresh, warm, sweet milk, thus giving a fresh sweet cream which, when properly cared for on the farm and delivered promptly to the factory, enables a higner quality product to be produced, an important factor in the marketing where discriminating trade is supplied.

Composition of Cream-The composition of cream will depend upon the amount of fat and skimmed milk it contains. If from 100 pounds of normal whole milk, containing $3.9 \%$ fat, all the fat be skimmed and enough skim milk be taken to make 10 pounds of cream, the 10 pounds of cream would contain 39\% fat, for 3.9 pounds of the 10 pounds would be fat.

If, instead of enough skim milk to make 10 pounds, an additional amount to make 20 pounds were taken, the percentage of fat would amount to $191 / 2 \%$ or $1 / 2$ the percentage in the former case.

In commercial practice, not all the fat is removed, as here assumed, but from $3 / 100$ to $5 / 100$ of $1 \%$ of fat remains in the skimmed milk. It is desirable that producers, manufacturers, and market men dealing in cream know these facts for the value 
of cream is dependent in large measure upon its quality and its fat content.

Advantages of Heavy Cream-Although 20 pounds of cream testing $191 / 2 \%$ fat contain the same amount of fat as 10 pounds of cream testing 39\%, it actually would have a less value to the butter manufacturer for he would have to provide twice the amount of cream vat space, twice the heat to pasteurize, twice the refrigeration to cool, and twice the churning space to churn.

But to the cream dealer or the milk distributor, the 20 pounds might have the higher value for it contains 10 additional pounds of skim milk which the milk dealer would have to supply if he received $39 \%$ cream and sold $191 / 2 \%$ or even lower testing cream.

Ordinarily, cream for table use contains from $12 \%$ to $18 \%$ fat, and cream for butter making, from $30 \%$ to $40 \%$ fat.

A high testing cream is also desired for buttermaking because the transportation costs are based upon the size of the can, and 10 gallons of $40 \%$ cream take the same rate as 10 gallons of $20 \%$ cream, yet on the basis of pounds of fat, it actually costs twice as much per pound butter fat to ship 10 gallons of $20 \%$ cream.

\section{Part II}

\section{CLASSES OF DAIRY MANUFACTURING PLANTS}

Commercial dairy plants may be grouped into two general classes:

$$
\begin{aligned}
& \text { 1-Processing plants } \\
& \text { 2-Manufacturing plants }
\end{aligned}
$$

\section{Processing Plants Defined}

In this group are included both country and city plants equipped to receive, cool, pasteurize, bottle, or otherwise handle milk and cream and pre- 
pare it for city distribution. Many such plants are also equipped to manufacture milk products and therefore would be included in both groups.

Manufacturing equipment is required in many processing plants for converting the surplus supplies of milk and cream into manufactured products. often an extensive manufacturing enterprise is conducted as a regular part of the business. Such enterprise usually includes the manufacture of butter or ice cream, or both. Often other products are manufactured such as condensed (whole) and powdered (skim) milk.

Manufacturing Plants Defined

In this group are included those firms which are engaged in the business of manufacturing dairy products. The business of such firms is less complicated, for ordinarily a single product is manufactured, although some firms may manufacture several products such as-

(a) Butter and casein; or butter, casein, and milk sugar

(b) Butter and evaporated skim milk; or butter and powdered skim milk

(c) Butter, cottage cheese, and ice cream

(d) Butter, and skim or part skim cheese

(e) Butter and condensed buttermilk

It will be noted that a variety of combinations is possible. In general, the kinds of products produced depend upon the kind and quality of raw material received, the kind of equipment in the plant, the training and skill of the employees, and the market prices obtainable for different products.

The markets available and prices obtainable for the secondary products in relation to the costs of raw material and manufacturing are factors which determine the practicability and profitableness of producing a variety of products. 
In lessons 3 and 4 , the business of manufacturing each of the more important dairy products will be treated in considerable detail. The remainder of this lesson will be devoted to a discussion of those products most important in dairy trade channels for a student of dairy marketing should know each thoroughly.

\section{Butter and Its Six Classes}

Butter is the product obtained by the churning of cream. Except when the cows are on fresh green grass pasture, it is the custom in commercial creameries to add to the cream before churning a harmless vegetable color in such amount as to give to the butter the natural tint of full grass butter.

How Butter Is Made-In the process of churning, the small microscopic globules of fat in the cream are united into granules, at first as small as pin points, then larger as the churning continues until they reach the size of large grains of wheat or small peas, when the churning is stopped and the buttermilk drained out.

It is common practice to wash the butter once or twice with water of about the same temperature as the buttermilk, thus removing the remaining buttermilk and leaving a clear brine in the butter.

The process of butter making is completed by salting the butter and working the salt uniformly through it as the butter granules are pressed into a uniform compact mass, in the churn or on the worker.

Six Classes of Butter-In commercial channels of trade, six classes of butter are recognized:

1. Farm or Dairy Butter

2. Creamery Butter

3. Processed Butter

4. Ladled Butter

5. Packing Stock Butter

6. Grease Butter 


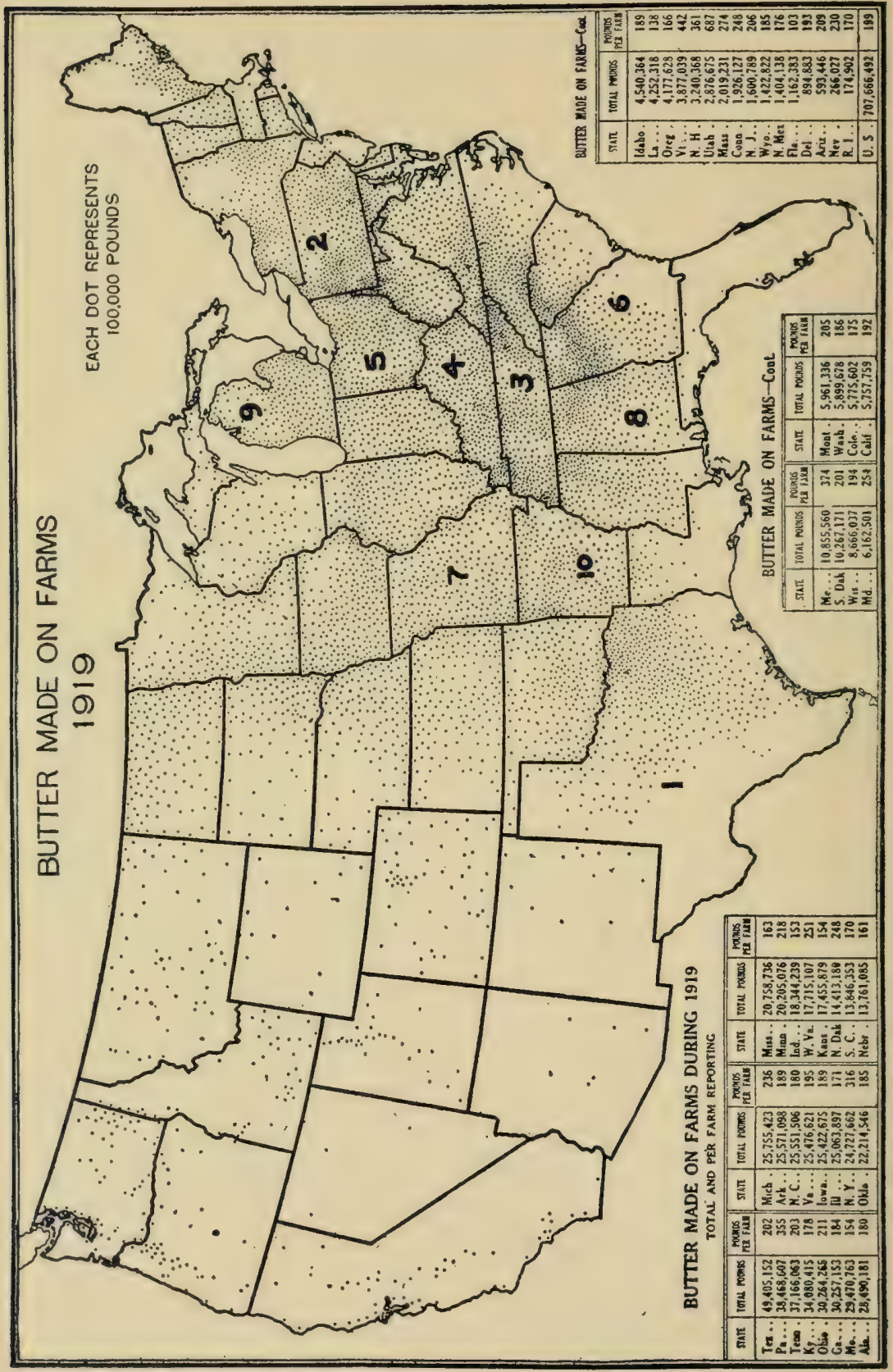

FIGURE 2. WHERE THE FARM BUTTER IS MADE

While Texas leads in the production of farm butter, she does not hold a very important place in the production of creamery butter, as you will see from Figure. 3. Compare these two maps carefully 


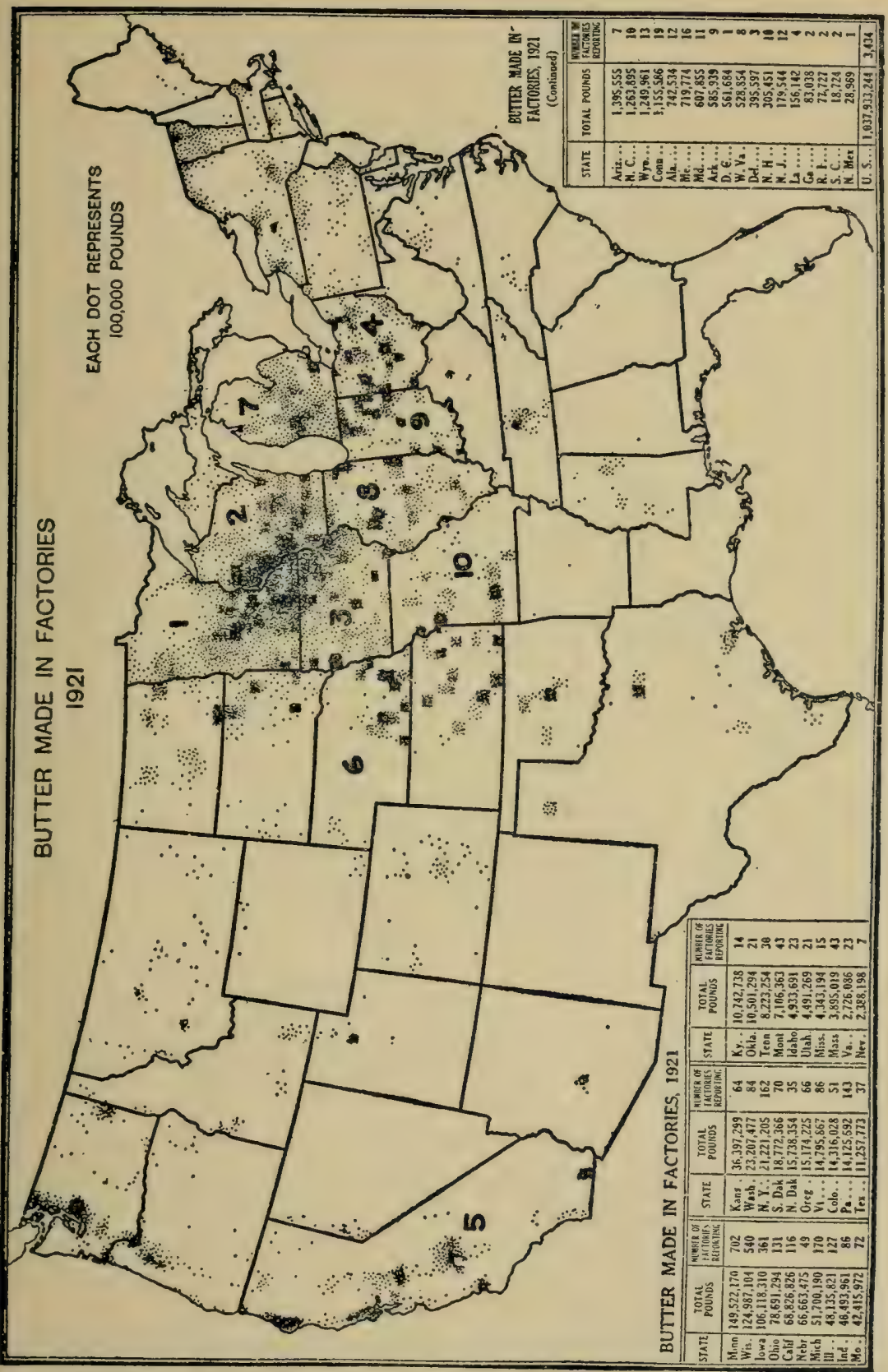

FIGURE 3. WHERE THE CREAMERY BUTTER IS MADE

In comparing this map with Figure 2, you will see that most of the states that hold important places in creamery butter production are comparatively backward in farm butter production 
Farm or Dairy Butter-is butter made on a farm from the milk or cream of not more than two dairy herds. As a commercial product, it is becoming of less importance each year, for the trend of butter production is toward an increase in factory or creamery butter production with a decrease in farm production. By far the greater part of dairy butter is consumed on farms or in the local villages and towns where it is marketed by farmers. As a commercial dairy product, dairy butter is becoming of less and less importance.

Process, Ladled, Packing Stock, and Grease Butter-are either lower grades of dairy butter, or products made from the lower grades. Grease butter is the lowest grade and, as its name signifies, is fit only for use as grease in soap making or for other purposes. It may be rancid, very sour, dirty, or otherwise unwholesome or unfit for food. Its value is very low.

Packing Stock Butter-consists of miscellaneous lots of dairy or farm butter packed in its original form in pails, tubs, barrels, or other bulk packages. It consists of the surplus farm or dairy butter which accumulates mainly at country stores, or butter of such inferior quality that it could not be sold to local customers.

It is packed into bulk packages to facilitate its shipment to market where the better lots are sorted out and $f$ ind their way into bakeries, and low class cafes, and restaurants.

The poor and fair-to-good lots are sold to ladlers and process butter manufacturers. Monthly reports of the stocks of packing stock butter in public cold storage are issued by the U. S. Bureau of Agricultural Economics.

Ladled Butter-is a product obtained by softening and ladling or reworking packing stock butter to which salt is usually added during the ladling 
process. Where a higher color is desired, the proper amount of butter color is thoroughly mixed with salt before it is sprinkled over the butter.

When the butter has become very soft, it is "sieved." Ladles with fine screen bottoms are manipulated under and lifted up through the butter, thus removing particles of paper or other foreign material that would be objectionable. With hand ladles or paddles, the butter is worked to a uniform color and consistency, when it is packed into prints or other forms of packages.

The principal outlet for ladled butter includes bakeries, low class cafes, and those who want cooking butter.

Its value depends upon its quality and, to a large degree, its use. Ladled butter, like process butter, is of importance primarily because it furnishes a market outlet for low grade dairy butter and packing stock. Also it is a source of low grade butter of wholesome quality, especially for baking and cooking purposes at prices below that of good dairy or creamery butter.

Process Butter-is the product made by melting other butter, draining off and recrystalizing the fat or oil, and then churning it with a carefully ripened starter milk, washing, salting, and working after much the same method as creamery butter is made.

Process butter manufacture is also a declining industry, the amount manufactured during the past five years being as follows:

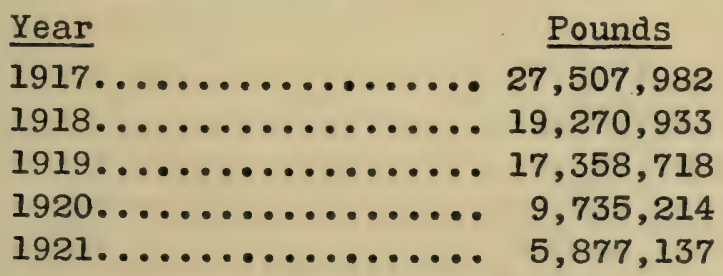

Process butter is widely distributed by the packers and has about the same ultimate market 
outlets and uses as ladled butter. The manufacture of process butter is under the supervision of the Dairy Division of the Bureau of Animal Industry of the U. S. Department of Agriculture, and reports of the monthly production are compiled and issued by the U. S. Bureau of Agricultural Economics.

Creamery Butter-is by far the most important of all classes of butter, the amount produced in 1921 being over one billion pounds, and for the preceding five years, according to government reports as follows:

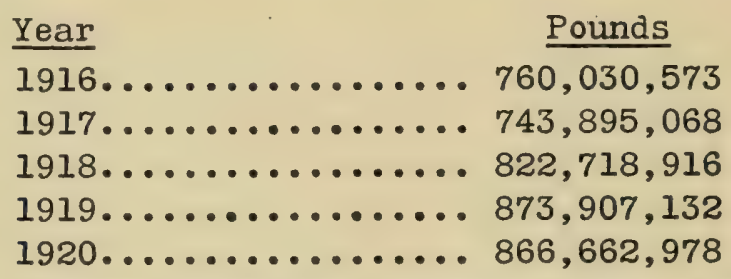

In a later lesson the creamery butter industry will be considered in much detail and very complete information given on every phase of the industry. It is well to state here that the composition of butter is subject to both federal and state regulations and because of the effect of different conditions and methods of manufacture, its composition is subject to considerable variation.

Composition of Butter-The following table gives the range of variation in the composition of butter and the general average for its composition:

Range General Average

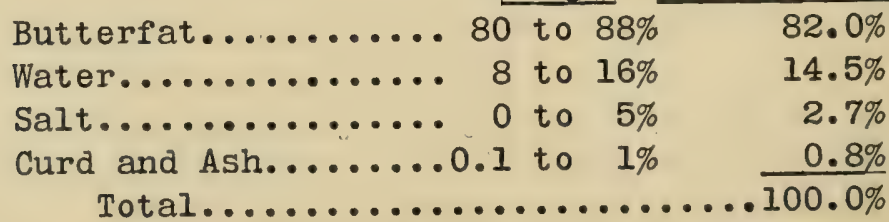

The maximum content permitted in unadulterated butter by federal standard and by most states is $16 \%$ and the minimum legal butterfat content is $82.5 \%$ with an allowed tolerance of $2.5 \%$ below this before 
reaching the limit at which prosecution under federal law is invoked.

These maximum limits on moisture, and minimum limits on butterfat, are of special significance to butter manufacturers, for in a case of violation of federal standards, the manufacturer is held liable, whether the butter is in his possession, or has been sold and is already in the distributing channels of trade.

\section{THE MANUFACTURE OF CHEESE}

Cheese is a product obtained (1) by coagulating milk with rennet or pepsin, or (2) by development of lactic acid as it sours, or (3) by addition of

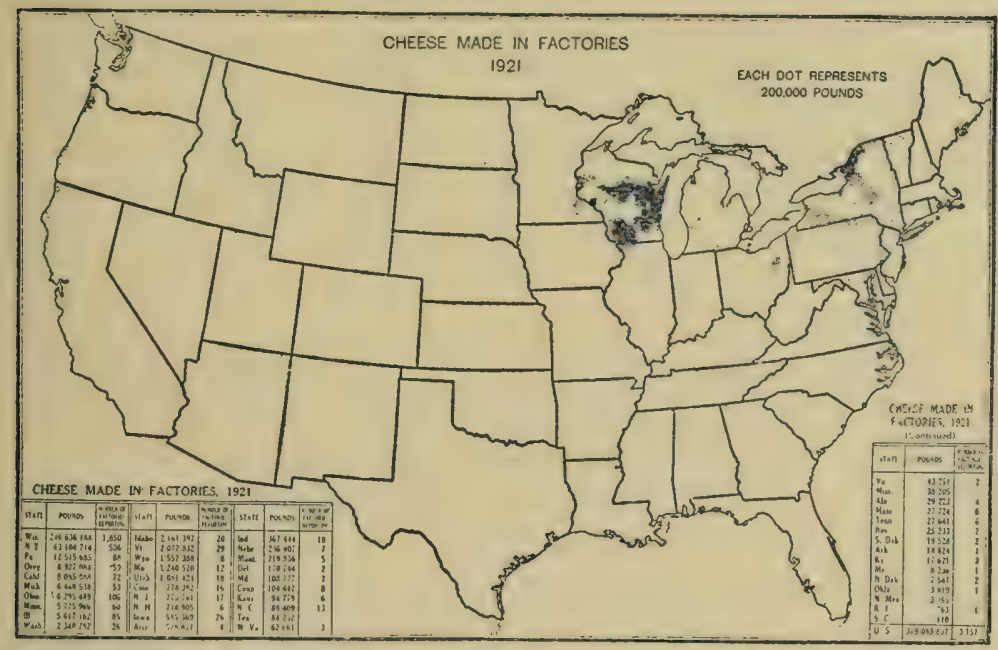

FIGURE 4. CHEESE MAKING LARGELY IN TWO STATES This map emphasizes the fact that 'Wisconsin and New York make most of the cheese. Wisconsin, in fact, makes more than all of the rest of the states put together

dilute commercial (Hydrochloric) acid. Except in special cases, the rennet process of coagulation of the casein is employed, and the surplus water is expelled from the curd by heat, which contracts it, thus forcing out the whey.

The two basic constituents of American cheese are casein and fat, which, with the moisture con- 
tent, comprise in most cheese fully $98 \%$ of its composition. Obviously, the coagulation of the casein into a curd, in which is held the fat, is an important part of cheese manufacture.

The sugar content remaining in solution escapes mostly with the water and forms a component part of the whey. It may be well to note here that milk sugar is ordinarily produced by crystalizing the sugar in cheese whey and refining it in the process of its manufacture.

Varieties of Cheese

The many different varieties of cheese are produced by different methods and conditions of manufacture.

The three most important commercial varieties of cheese are American, Swiss, and brick. The discussion here, and a later lesson on the cheese industry, will be chiefly concerned with the first two varieties.

\section{American Cheese}

American cheese is the variety most of ten sold in retail grocery stores, and when the word "cheese" is used, it is American cheese that is generally meant. It has a variety of trade names such as "store cheese", "colored cheese", "cream cheese", "Wisconsin cheese", etc.

When uncolored, - that is, when made without the addition of cheese color to the milk before adding the rennet-it is often known as "New York Cheese", especially in western markets.

Different Processes of Manufacture-The general process of manufacture of American cheese is subject to variation resulting in different body and texture, or degree of openness and firmness. This condition results in marked differences in the commercial quality of cheese and the adaptability of the cheese to meet different preferences of the 
trade. Some sections of the trade like a soft, open texture and body, while others prefer a firm, close texture and body.

The effort of manufacturers to produce cheese to suit the marked differences in preferences of the trade has resulted in a great lack of uniformity in methods of manufacture as well as in quality of product.

Market men need to understand these conditions in the cheese industry, in order to realize how complex and costly may be the problem to supply each particular market demand with the special type and style of cheese it requires.

\section{Various Styles of American Cheese-Another} interesting fact to note regarding American cheese is the many styles in which it is made and marketed. Originally in New York factories, it was made for export to weigh 60 pounds or more. But now it is made In the styles having the weights given in the following table:

Table I. Styles of American Cheese

\begin{tabular}{|c|c|c|c|c|c|c|c|c|}
\hline Style & $:$ & $\begin{array}{l}\text { Diam- } \\
\text { eter } \\
\text { Inches }\end{array}$ & : & $\begin{array}{l}\text { Height } \\
\text { Inches }\end{array}$ & : & $\begin{array}{l}\text { Weight } \\
\text { Pounds }\end{array}$ & $:$ & $\begin{array}{c}\text { Number packed } \\
\text { per box }\end{array}$ \\
\hline & : & & : & & : & & : & \\
\hline Cheddar... & & $14 \frac{1}{2}$ & : & 12 & $:$ & $65-66$ & : & 1 \\
\hline Flat..... & & $14 \frac{1}{2}$ & : & $5 \frac{1}{2}$ & : & $30-33$ & : & 1 or 2 \\
\hline Daisy..... & & $13 \frac{1}{2}$ & : & 4 & : & $20-25$ & : & 1,2 or 3 \\
\hline Young & : & & : & & : & & : & \\
\hline America.. & & 7 & : & 7 & : & $10-11$ & : & 4 \\
\hline Longhorn.. & & 4 & : & 12 & : & $12-13$ & : & 4 \\
\hline & : & & : & & : & & : & \\
\hline
\end{tabular}

Why Different Styles Are Manufactured-These different styles have each been the result of a market demand or, rather, the attempt of manufacturers to produce a style which would be received with favor on the market. 
The "flat" as will be noted from the table is a little less than half as high as a "cheddar." It was probably produced to meet the demand of trade which had a very limited sale for cheese and needed a smaller style than a cheddar.

A "daisy" is practically a small sized flat. This style has been made principally in Wisconsin to meet the requirements of southern trade which also is of a limited sort and naturally demands a small size cheese.

The "Ionghorn" is distinctly of Wisconsin origin and, like the "young America", is especially suited to hotel, restaurant, and delicatessen trade where small slices are mostly required and a minimum of waste and drying out of the cut surface is desired.

The "square print" was originated also in Wisconsin but has never come into very large demand, because it is more costly to make, sells at a higher price, and its sale has never been pushed by the trade.

Each of these styles has its particular merits and is of importance, but there is no doubt that either the daisy or flat could be dispensed with or a compromise size made to serve the purposes of both.

Also the longhorn and young America are so closely alike that a compromise between them might well take the place of both.

\section{Swiss Cheese}

Swiss cheese is made by a special process, the milk being heated and coagulated in copper kettles with round bottoms. The curd is removed in one piece by using a half hoop which carries the draining cloth under the curd and enables the curd to be lifted from the kettle and placed in the hoop to drain and take form.

A special culture of bacteria which produces the formation of "eyes" is added to the milk before it is 
coagulated, and the development of the eyes is controlled by the temperatures maintained in the curing rooms.

The salting of the cheese is accomplished by holding it in a brine solution for several days during the process of manufacture.

Ordinarily, the cheese should be held in the curing rooms for three months or more beiore it is marketed, but in recent years, the tendency is to put the cheese on the market as soon as it shows good "eye" development and the characteristic Swiss flavor is fairly well developed.

This practice should be discouraged for it only results in greater discrimination against domestic Swiss and in favor of the imported which shows exceptionally fine large "eye" development and a fully developed characteristic flavor.

Two Styles of Swiss Cheese-Swiss cheese is marketed in two styles, "wheel" or "drum", and "block." The wheel or drum style weighs about 100 pounds and measures about 28 inches in diameter with a thickness of about 7 inches. This style is packed two or three in a case.

Block Swiss measures about six inches by six inches and 26 inches long. This style weighs about 30 pounds each. It is regularly packed with six in a box placed side by side.

The "eye" development and characteristic flavor of block Swiss is somewhat less than that of the wheel or drum style, and the price is usually somewhat less. The block Swiss is most in demand by small retailers whose sales are limited and by restaurant trade, which finds it specially well suited for sandwich making.

\section{- CONDENSED AND EVAPORATED MIIK}

These products are very much alike in composition, except that condensed milk contains approximately $35 \%$ of cane sugar. This additional sugar 
gives condensed milk a heavier creamy or syrupy consistency, making it specially adapted for use where cream and sugar are used together as on cereals and in coffee.

Condensed milk is marketed in cases and in bulk, the former being, in the main, for household use and the latter for wholesale trade such as bakeries, confectioneries and ice cream factories.

\section{Manufacture of Condensed and Evaporated Milk}

In the manufacture of condensed and evaporated milk, a very high quality of milk is required for the production of the highest quality of product. It must be perfectly sweet and of fine flavor. In the condensing pan, it is heated to a temperature of about 135 degrees Fahrenheit under a vacuum of 25 inches, and water evaporated until the milk has been reduced to about $3 / 5$ of its original volume.

The evaporated product has about $2 \frac{1}{2}$ times the per cent of total solids in normal milk.

The milk to be marketed as evaporated usually is passed from the condensing pan through an homogenizer into the final containers where it is hermetically sealed. It is later placed in a steam pressure sterilizer where it is held for 15 minutes or more until it has been thoroughly sterilized, thus insuring its keeping quality as a sterile product. Condensed milk, i.e., the sweetened product, is not sterilized as its sugar content contributes to its keeping quality.

\section{Packing of Condensed and Evaporated Milk}

Condensed and evaporated milk are packed in large and small cans, the standard large size for each being 16 ounces for evaporated and 14 ounces $f$ or condensed. In the usual channels of trade, these products are sold to the retailers by manufacturer's agents and wholesale grocers. Shipments are made usually in carload lots from the factories to the 
agents or wholesale grocers who, in turn, ship or deliver to the retailer the exact number of cases of each size can of each product required by his trade.

\section{MILK POWDER}

This is one of the newer milk products which has come into quite general use among food products manufacturers, such as bakers and ice cream producers. It has also been received with favor in many households.

Milk powder is manufactured from either skim milk, whole milk, or cream and the resulting product is known as skim milk powder, whole milk powder, or cream powder. Except for a small percentage of water or moisture in milk powder, it has the same relative composition as the total solids content of the milk or cream from which it was made.

\section{Uses of Milk Powder}

The general uses of milk powder correspond to the product from which it was made, for most powder is readily soluble in water and, when the proper amount of water is added to the powder and it is dissolved, it has practically the same flavor, taste, and characteristics of the original milk. The whole milk powder is used for infant feeding, and the skim milk powder by food products manufacturers.

\section{Manufacture of Milk Powder}

In the manufacture of milk powder, a pure, wholesome, quality of fresh milk is required. The milk to be powdered is partially condensed by some powder manufacturers before it is sprayed into the hot dry atmosphere in the dryer where it falls as a powder to the bottom.

\section{Buttermilk Powder}

It may be well here to mention buttermilk powder which has come into commercial use especially 
in the preparation of pancake flours and self-rising biscuit flours, also as a component part of prepared commercial poultry and stock foods.

This product has not been put generally into retail stores as its use would be rather limited. It is made by powdering wholesome sour milk or buttermilk. When water is added to the powder, a product results with the same characteristics as the products from which it was made.

\section{WHERE DOES THE BAD BUTTER GO?}

From Iesson 2 you have very clearly in mind that butter and cheese are the two principal prouucts manufactured from milk and cream. And so you realize the necessity for knowing all about the manufacture of butter and cheese. subject.

The next lesson is devoted entirely to that

You, no doubt, have wondered what becomes of the great mass of dairy butter that is taken in exchange for merchandise at country stores. No doubt you have seen some of that butter dumped into barrels in the back room of the store and have wondered if any of it might eventually come back to your own table.

What becomes of the butter that turns rancid and becomes unfit for food?

Why is it that local creameries are fast disappearing from most sections?

Why does Wisconsin make more cheese than all of the other states put together?

Why is it that much of our Swiss cheese is made right here in America?

These are just a few of the fascinating subjects that you will find in Lesson 3 . 


\section{GLOSSARY OF MARKETING TERMS USED IN THIS LESSON}

block Swiss cheese, A market form of Swiss cheese made by matting Swiss cheese curd and then compressing it into the form of a block, usually 25 inches long and six inches square; each cheese weighs about 30 pounds.

brick cheese, A type of cheese made in a shape somewhat resembling a brick; it is about the length of a building brick and about the same width, but usually about twice as thick.

Cheddar, n. A style of cheese made in a circular block, 141/2 inches in diameter, 12 inches high, and weighing from 65 to 66 pounds.

cottage cheese, Cheese made by coagulating skimmed milk usually by natural souring and heat, then draining off the whey.

daisy, n. The name of a style of cheese, which is pressed into a circular form about $131 / 2$ inches in diameter and four inches high, and which weighs about 20 or 25 pounds.

drum Swiss cheese, A market form of Swiss choese that weighs about 100 pounds and measures about 28 inches in diameter and about seven inches thick. It is the same as a wheel or tub Swiss cheese.

flat, adj. A style of cheese made in circular form, weighing 30 to 35 pounds, and measuring $141 / 2$ inches in diameter and $5 \frac{1}{2}$ inches high.

grease butter, The lowest grade of butter, and f1t only for use as grease in soap making or for similar purposes; it may be rancid, very sour, dirty, or otherwise unfit for food.

ladled butter, A product obtained by softening and re-working packing stock butter, to which salt is usually added during the ladling process.

Iimburger cheese, A variety of cheese that is soft, but very strong in taste and odor; named for the province of Limburger in the Netherlands, where it was first made.

Ionghorn, n. A style of cheese of the form of a cylinder, four inches in diameter and 12 inches high, and weighing from 12 to 13 pounds. 
overhead operating cost, Fixed charges in the operation of a factory or a business, which charges do not vary materially one way or the other as the amount of business done or product manufactured, fluctuates.

packing stock butter, Miscellaneous lots of dairy or farm butter in its original form, packed in pails, tubs, barrels, or in other packages. It is the surplus that accumulates at country stores; it usually is of such inferior quality that it cannot be sold to local customers.

process butter, The product made by melting butter and then churning it with a carefully ripened starter milk, the object being to again collect the fat globules. The method of manufacture after churning is done, is approximately the same as the making of creamery butter.

Roquefort cheese, A cheese originally made from the milk of sheep; the cheese after being made is ripened in caves, and when offered for sale is streaked with a greenish mold; now made also from cow's milk.

sieved butter, Butter, through which ladles with fine screen bottoms are manipulated for removing particles of paper or other foreign material that might make the butter objectionable for food; the same as ladled butter.

Swiss cheese, A cheese originated in Switzerland; it is neither hard nor soft, and is commonly a light yellow in color. Most of it is still made in Switzerland, but some is made in America and other countries. It is characterized by large holes that develop through the cheese. However, a market form of Swiss cheese known as "block Swiss" cheese does not have the large holes in it, due to the fact that the cheese has been matted and pressed into a block. vegetable color, Coloring matter derived from vegetable sources used in the making of butter. wheel Swiss, A market form of Swiss cheese weighing about 100 pounds, and measuring about 28 inches in diameter, with a thickness of about seven inches; it is made in the shape of a wheel and is the same as "drum" or "tub" Swiss.

Young America, A style of cheese made in a circular form, seven inches in diameter, seven inches high, and weighing from 10 to 11 pounds. 

LIBRARY OF CONGRESS

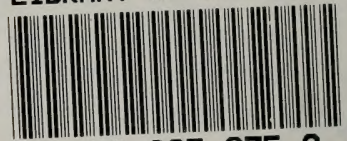

00008952759 